\title{
MAINTENANCE PERFORMANCE RESEARCH - PART 1: A REVIEW OF MODELS AND ISSUES
}

\author{
S.A. Oke \\ Department of Mechanical Engineering \\ University of Lagos, Nigeria \\ sa_oke@yahoo.com
}

\begin{abstract}
The paper presents a comprehensive review of maintenance performance research. Articles on general surveys, system modelling, and specific applications in industries are reviewed. The scientific principles underlying maintenance performance research for the past 30 years are considered. The body of knowledge on maintenance performance is both quantitatively and qualitatively based. Of the quantitative approaches are economic and technical ratios, value-based and balanced scorecard, system audit, strategic, composite formulation, statistical, and partial maintenance productivity indices. The qualitative approaches include Luck's method, among others. Qualitative-based approaches are adopted in view of the inherent limitations of measuring a complex function such as maintenance effectively through quantitative models. Maintenance decision makers often come to the best conclusion using heuristics, backed up by qualitative assessment, supported by quantitative measures.
\end{abstract}

\section{OPSOMMING}

Die artikel lewer ' $n$ omvattende oorsig van navorsing oor instandhouding. ' $n$ Aantal artikels oor algemene opnames, sisteemmodellering en nywerheidstoepassings word behandel. Die beginsels en praktyk van instandhoudingsvertoning moet deeglik verstaan word voordat die leser poog om navorsingsbronne ten beste te kan benut. Die versamelde kennis oor instandhoudingsvertoning is gebaseer op kwantitatiewe en kwalitatiewe beginsels. Die spektrum van kwantitatiewe metodes is uitgebreid en uiteenlopend. Die kwalitatiewe metodes word ook betrek om die kompleksiteit van instandhoudingsvraagstukke te behandel. Dit is dikwels so dat besluitvormers die beste oplossings vind op grond van heuristiese metodes gebaseer op kwalitatiewe en kwantitatiewe beskouings. 


\section{INTRODUCTION}

World-class manufacturers (WCM) have realised the need to continuously improve their operations in order successfully meet global competition. The high productivity expected from manufacturing systems, high capital cost of modern production machines, as well as the high maintenance cost of such units dictate an intensive approach to maintenance management [3, 62]. In addition, the maintenance department is confronted with the challenge of quality improvement, cycle time, setup time, and cost reductions, capacity expansion, and related environmental issues (cited in [31]). Maintenance organisations around the world are therefore making efforts at increasing their organisational capabilities by making investments in performance-enhancing programs, maintenance paradigms, initiatives, and practices such as total quality maintenance (TQM), business process reengineering (BPR), and total productive maintenance (TPM), reliability-centred maintenance (RCM), condition-based maintenance (CBM), computerised maintenance management system (CMMS), and audit systems (AS), among others [2, 58, 60, 61, 77]. All these have emerged in response to competitive pressures demanding shorter lead times, increased responsiveness, improved product quality, and lower cost of production and services. This has therefore triggered the elimination of waste through maintenance process simplification, set-up time reduction, material flow control, and an emphasis on preventive maintenance.

To enhance these systems-thinking philosophies, maintenance organisational capabilities have been greatly expanded by the rapid development of the global interconnected infrastructure, which makes maintenance information accessible from different security domains for quality decision making. Furthermore, the Internet and the Web offer means of collecting and sharing maintenance data and information with unprecedented flexibility and convenience.

However, most of the highly publicized philosophies or techniques noted above (i.e. RCM, CBM) are introduced haphazardly in the maintenance organisation, yielding sub-optimal results $[3,13]$. This causes serious concern to both practitioners and researchers, thus, stimulating an increasing number of investigations (see[10, 12, 24]). Maintenance is considered a tactical matter with strategic dimensions, covering issues such as design of facilities and their maintenance programmes, upgrading the knowledge and skills of the workforce, and deployment of tools and manpower to perform maintenance work [24, 37, 77, 80].

Nowadays, maintenance budgets are large. Maintenance-related costs are at least as high as the direct costs included in these budgets with maintenance labour costs increasing faster than the total operating index. Furthermore, the impact of maintenance on production and operation aspects such as capacity, quality (in ISO 9000 standards maintenance is explicitly expounded), cost, environmental and employee safety, is considerable [69]. Consequently, maintenance has played a key role in an organisation's long-term profitability and has increasingly become a part of a total performance approach, together with other topics such as productivity, quality, safety, and environment $[25,64,76]$. This has been reflected in the desire of 
organisations to improve maintenance performance $[10,26,28,29,35,38,39-41$, 46].

This study is principally motivated by the increasing interest in the maintenance performance system, which has been studied by many researchers [19, 34, 74, 84]. Unfortunately, the measurement of maintenance performance remains a complex issue, the success of which largely depends on an in-depth practical field experience, and a well-structured methodology for measurement and auditing [1, 6-10, 12, 14, 36].

This paper presents a general overview of significant research on maintenance performance and opportunities for further exploration. The purpose is to provide the reader with an insight to developments in the area of maintenance performance in general. This work would be useful for future investigators involved in maintenance performance research that seek a broad-based understanding of the area. It gives the reader an understanding of the wide range of topics involved, an impression of the length and breadth of this interdisciplinary academic field, and the wide-ranging practical management applications.

The remaining sections of this paper are structured into two sections. Section 2 deals with the different treatment methods in the maintenance performance literature. Six methods are discussed. The first method provides an insight into the economic and technical approach. Method 2 discusses the strategic approach to maintenance performance research. The system auditing approach is discussed as the third method. Method 4 is an analysis of the statistical/reliability/maintainability functional approach. For method 5, attention is focused on the composite formulation approach. The last method discussed is the partial maintenance productivity approach. Section 3 concludes the study.

\section{TREATMENT METHODS IN MAINTENANCE PERFORMANCE}

The literature review draws from prominent studies that have addressed the maintenance performance measurement problem specifically [69, 70, 79, 81, 83]. Several studies have been carried out using performance criteria such as productivity $[11,17]$, profitability, efficiency, effectiveness [20, 21, 32, 58, 66, 73], innovation, and quality of working life, etc. Generally speaking, the important areas of maintenance performance and the structure of the current review work are illustrated in the diagram below (Figure 1). The various applications of maintenance performance are found in manufacturing, mining, transportation, utilities, petrochemical, healthcare facilities, and the process industry, etc.[3, 42-44, 45, 48, 54, 67]. In section 2.7 (part 2), the reader is assisted in identifying profitable approaches to adopt in practice with the use of some model evaluation criteria. The following is a brief summary of prominent sections of the maintenance performance research [75, 81, 84]. The treatment methods represent the general approaches adopted in the literature for theoretical and practical analysis, modelling, and decision making. 


\subsection{Treatment method 1: Economic and technical approach}

Since maintenance performance is generally difficult to measure, professionals do not only consider quantifiable parameters but also the quality of the performed maintenance and its organisation. Consequently, performance parameters are defined in relative values, i.e. true ratios broadly defined as economic and technical $[10,71$, 72]. Other authors such as Jooste and Page [19] refer to it as financial and nonfinancial ratios respectively. De Groote [10] defines economic ratios as elements, which allows the follow up of the evolution of internal results and certain comparisons between maintenance services of similar plants. Technical ratios are elements, which give the maintenance manager the means of following the technical performance of the installation. In particular, economic ratios are linked to maintenance cost. Nine economic ratios are defined here $[5,49,60]$ : The first ratio is

Direct cost of maintenance

Added value of production

The direct cost of maintenance is expressed in terms of cost of manpower, cost of materials (spare parts, lubricants, miscellaneous), cost of subcontracted work and overheads. The components of the added value of production are the total cost of production less the cost of raw materials. The second ratio is defined as:

Cumulative costs of maintenance of a production unit since start - up

Number of operating hours since start - up

This ratio links the total direct cost of maintenance to a time unit. The third ratio is:

Total maintenance manpower cost

Total direct maintenance cost

The fourth and fifth ratios in this category are defined as:

Average stock value

Replacement value of production equipment

and

Cumulated value of issued spares over a 12 - month period

Average stock value over a 12 - month period

The fourth ratio takes into account the components of maintenance costs in relation to exterior ones while the fifth ratio gives the stock rotation. This is the number of times the value of the stock is issued per year. The sixth ratio, which eliminates the safety-parts issues in the ratio of stock rotation, is defined as follows: 
(Cumulated value of issues over 12 months - Cumulated value of issues of safety parts over 12 months) / Average stock value without safety parts

Three other ratios are:

Total store issues and direct purchases

Total direct maintenance cost

Cost of subcontracting (manpower)

Direct cost of maintenance

Cost of maintenance personnel

Direct cost of maintenance

The first of the three ratios defined above relates to the consumption of store items. The second follows the evolution of the policy adopted for subcontracting [50,82], while the third shows the impact of fixed or temporary personnel on the maintenance system.

Apart from the economic ratios defined above, the following additional ratios (i.e. financial) are used in the literature: Return on Total Assets (ROTA), opportunity costs, alternative comparison and replacement analysis. This is particularly emphasized in asset management environments (see [19]). Mathematically, the expressions are:

ROTA $=\frac{\text { Earnings Before Interest and Tax }}{\text { Total Assets }}$

ROTA $=$ Profit Margin $\mathrm{x}$ Asset Turn

ROTA $=\left(\frac{\text { Earnings Before Interest and Tax }}{\text { Sales }}\right) \times \frac{\text { Sales }}{\text { Total Assets }}$

where ROTA is calculated as a percentage and represents the operating efficiency and productivity of an enterprise and is independent of how a company is financed. Also,

ROTA $=\left(1-\sum_{i} \frac{\mathrm{C}_{\mathrm{i}}}{\text { Sales }}\right) \times\left[\sum_{j}\left(\frac{\text { Sales }}{\mathrm{A}_{\mathrm{j}}}\right)^{-1}\right]^{-1}=\left(\frac{\text { Sales }-\sum_{i} \mathrm{C}_{\mathrm{i}}}{\sum_{j} \mathrm{~A}_{\mathrm{j}}}\right)$

where $C_{i}$ is cost item $i$ in the collection of expenses, before tax and interest deductions, in the profit-and-loss statement and where $A_{j}$ is the value of asset type $j$ in the collection of total assets in the balance sheet. Opportunity cost from an asset management perspective is the monetary value of the lost capacity due to underperforming assets or questionable policy decisions [19]. By expressing Overall 
Equipment Effectiveness (OEE) and Overall Plant Performance (OPP) in units transferred it is possible to calculate the opportunity costs. Opportunity costs

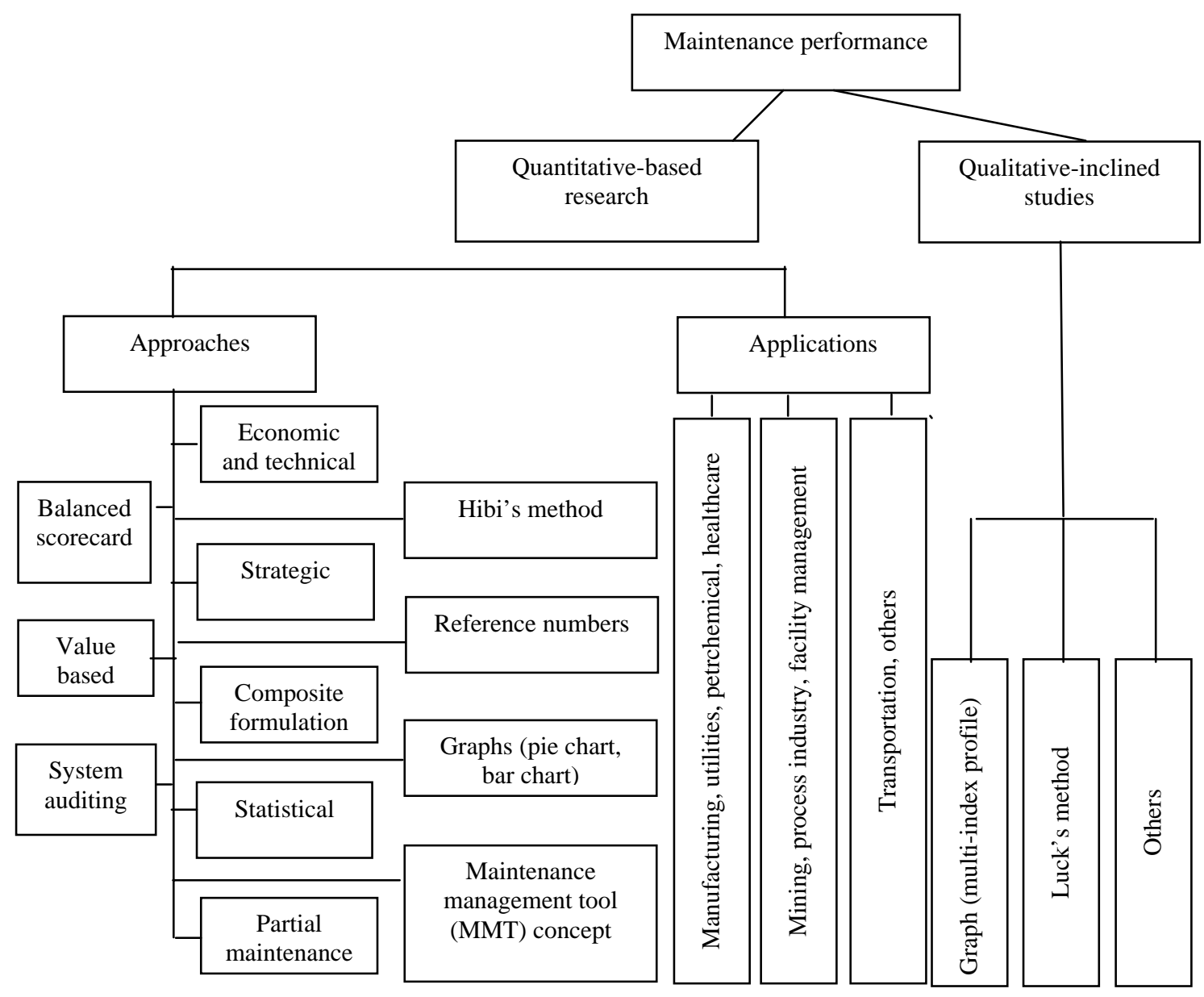

Figure 1: A model showing the diverse approaches, applications and structures of maintenance performance literature

calculated from OEE ( $\left.\mathrm{OC}_{\mathrm{OEE}}\right)$ monitors asset practices, while the respective opportunity cost for OPP (OC $\left.\mathrm{OPP}_{\mathrm{OP}}\right)$ monitors policy decisions. $\mathrm{OC}_{\mathrm{OEE}}$ and $\mathrm{OC}_{\mathrm{OPP}}$ are calculated as follows:

$\mathrm{OC}_{\mathrm{OEE}}=$ (Theoretical Units in Loading Time - Sellable Units) $\mathrm{x}$ Unit Price

$$
=\left(\frac{\text { Sellable Units }}{\text { OEE }}-\text { Sellable Units }\right) \times \text { Unit Price }
$$

From a traditional perspective $\mathrm{OC}_{\mathrm{OEE}}$ would be an efficiency index. For consistency, it is considered as an opportunity cost in the asset management context.

$\mathrm{OC}_{\mathrm{OPP}}=($ Theoretical Units in Total Time - Sellable Units $) \times$ Unit Price 


$$
=\left(\frac{\text { Sellable Units }}{\text { OPP }} \text {-Sellable Units }\right) \text { x Unit Price }
$$

Recall that De Groote [10] defined maintenance performance in terms of two ratios: economic and technical. The proceeding paragraphs have dealt with the economic ratios. The technical ratios are hereby discussed. The technical ratios are far more numerous than the economic ratios and are placed under two categories: (i) those which interest the user of the equipment and are a measure of efficiency; (ii) those which directly interest the maintenance manager in measuring the efficiency of maintenance policy. An overall equipment effectiveness indicator (OEE) covers both, which is a company or production sector performance indicator [10, 61], represented in Figure 2 below.

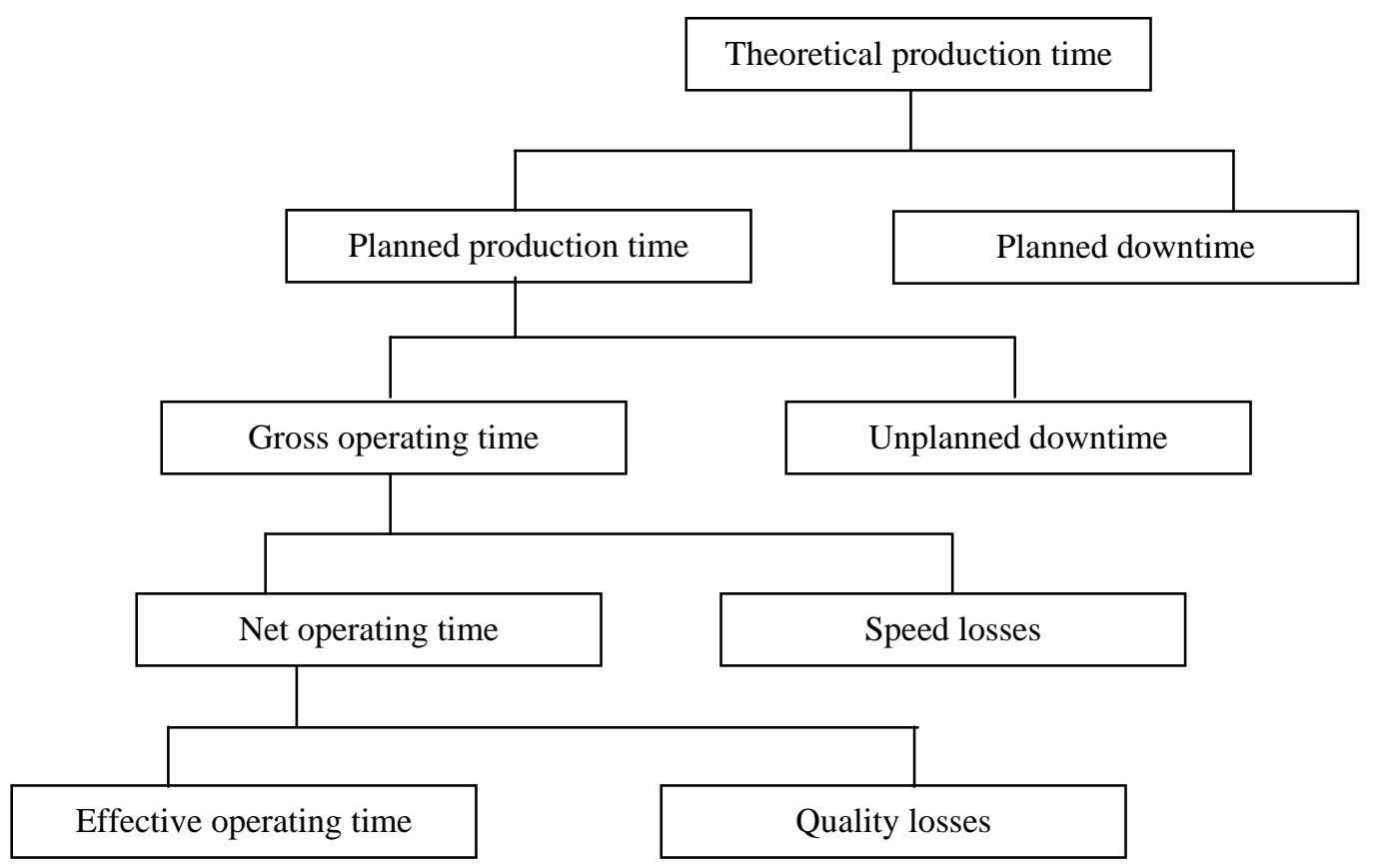

Figure 2: Overall equipment effectiveness (OEE) indicator [10]

In Ljungberg's [49] case study conducted at a Swedish car factory, the overall equipment effectiveness (OEE) was estimated to be on average around 55\%. Thus, it is possible for manufacturing industry to increase its production capacity without investing in new machinery if an efficient maintenance policy is implemented, as discussed by Al-Najjar and Alsyouf [2]. The OEE performance measure may support less delivery delay, i.e. more accurate delivery schedules by using an efficient and continually improved maintenance policy to detect deviations (and eliminate causes) in machine condition at an early stage. This would result in increased market share and enhance reputation for the company [2]. Nakajima [61], the author of the total productive maintenance (TPM) philosophy, advocates OEE as a metric for the evaluation of equipment effectiveness. OEE is often used as a driver for improving performance of the business by concentrating on quality, productivity and machine utilization issues and hence aimed at reducing non-value adding activities often inherent in manufacturing processes [4]. 
The technical ratios are stated below [4, 49].

The following formulae are applicable: OEE = A x S x Q where

Availability Indicator (A):

Planned production time - Unplanned downtime

Planned production time

Speed (amount of production) Indicator (S):

Actual amount of production

Planned amount of production

Quality Indicator (Q):

Actual amount of production - Non - accepted amount

Actual amount

The total company or production sector performance: OEE x P, where

Planning Indicator (P):

Theoretical production time - planned downtime

Theoretical production time

Time during which the equipment should normally be in production:

Theoretical production time - Hours of maintenance (planned and unplanned)

Theoretical production time

The ratio of operational availability, influenced by maintenance:

Number of gross operating hours / (Number of gross operating hours + Downtime for maintenance (planned and unplanned))

This ratio represents the lost production hours due to unplanned downtime (breakdown) for maintenance reasons:

Number of hours of downtime for unplanned maintenance

Number of gross operating hours

This ratio characterizes the number of failures in the system per unit of time and is a measure of the failure or breakdown rate: 
Number of production stops

Number of gross operating hours

This ratio measures the evolution of the state of material. It can provide a forecast, by material group, of the maintenance workload for the personnel:

Number of maintenance hours (planned and unplanned)

Number of gross operating hours

This ratio measures the efficiency of the maintenance policy:

Number of man hours for troubleshooting

Number of man hours for planned maintenance

This ratio measures the level of work preparation. It can be a sign of the efficiency of the maintenance organization:

Man - hours spent on prepared work

Total man - hours spent by maintenance personnel

This ratio gives an indication concerning the performance of interventions:

Sum total of time allocated for maintenance work

Sum total of time actually worked for these jobs

Apart from the technical ratios stated above, the following ratios also fall under the non-financial (technical) ratios:

Utilization $=\frac{\text { Loading Time }}{\text { Total Time }}=\frac{\mathrm{B}}{\mathrm{A}}$

where Loading Time $=$ Total Time - Authorized Downtime

Availability $=\frac{\text { LoadingTime- }(\text { Unauthorized Downtime }+ \text { DeviationTime })}{\text { LoadingTime }}=\frac{\mathrm{C}}{\mathrm{B}}$

Performance $=\frac{\text { Actual Production } \mathrm{x} \text { Technical Cycle Time }}{\text { Operating Time }}$

$=\frac{\text { Actual Production }}{\text { Operating Time } \mathrm{x} \text { Standard Speed }}$

where Operating Time $=$ Loading Time - Unauthorized Downtime + Deviation Time 
Quality $=\frac{\text { Good Production }}{\text { Actual Production }}=\frac{E}{D}$

where, Good Production = Gross Production - Startup Defects - Quality Defects

OEE $=$ Availability x Performance $\mathrm{x}$ Quality

OPP = Utilization x Availability x Performance x Quality

It should be noted that OEE is a shop floor improvement tool addressing how effective factories run their processes when scheduled to run. Overall Plant Performance (OPP) includes utilization of total time. It gives an indication of asset performance relative to each minute of the clock (operation time and authorized downtime) and not only operating time (actual operation time exclusive of authorized downtime) [19].

\subsection{Treatment method 2: Strategic approach}

The strategic approach relates to strategic issues of acquisition, improvement, replacement and disposal of physical assets [80]. This approach to maintenance

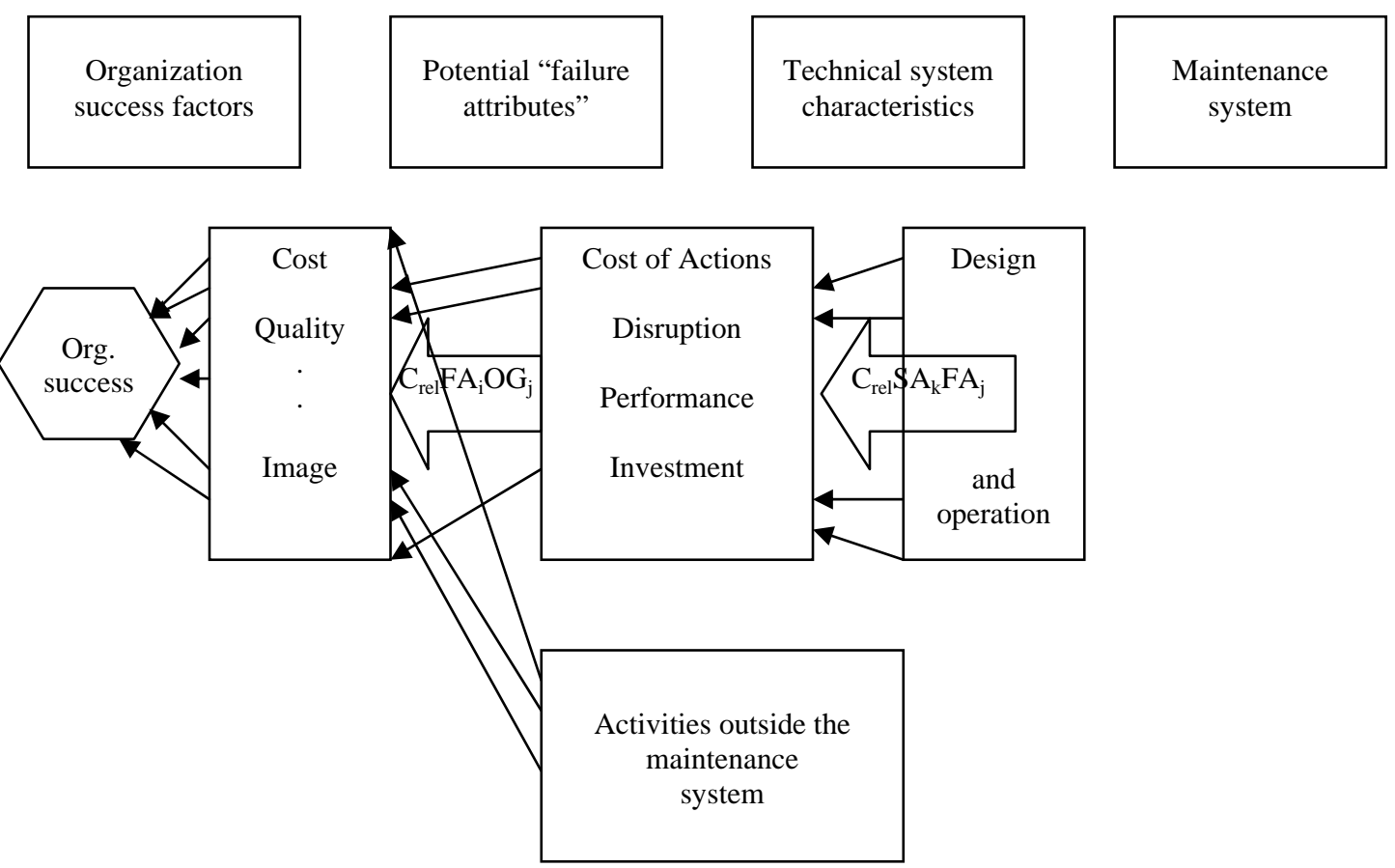

Figure 3: Systems auditing approach [80]

reflects the maintenance organization's conception of its intended long-term goal [80]. In adopting this approach to the measurement of maintenance performance, the maintenance strategy is linked to the corporate strategy. Three common examples of maintenance strategies that relate to maintenance performance measurement are maximization of asset utilization, improvement of responsiveness of maintenance to customer needs, development of core competencies in maintenance areas. The 
success of the strategic maintenance performance management approach built on an understanding by the stakeholders of the compelling need to change, a shared vision of future performance, commitment, deployment of the needed resources, feedback of progress made, constant communication as well as a reinforcing reward and recognition system [80].

\subsection{Treatment method 3: System auditing approach}

System auditing approach focuses on the system and its attributes rather than specific outcomes $[12,78,80]$. It concentrates on the maintenance system itself as opposed to quantifying its inputs and outputs. It is anticipated that the results from such an approach yield a level of accuracy that is compatible with the information normally available about real performance. Figure 3 illustrates some of the basic processes in the systems audit approach.

The systems audit approach is represented by a transformation coefficient or coefficient of influence, $\mathrm{C}_{\mathrm{rel}} \mathrm{SA}_{\mathrm{k}}$, and the correlation between the performance of a particular system element or activity and the organization's success, $\mathrm{C}_{\mathrm{rel}} \mathrm{SA}_{\mathrm{k}}$ which is built up according to $[78,80]$ :

- to relationship between the failure attributes, $\mathrm{FA}_{\mathrm{i}}$, addressed by the system activity and business success $\mathrm{C}_{\mathrm{rel}} \mathrm{SA}_{\mathrm{k}}$; and

- the system activity's potential to influence technical system performance relative to the failure attributes, $\mathrm{C}_{\mathrm{rel}} \mathrm{SA}_{\mathrm{k}}$.

An expression for performance encapsulating $\mathrm{C}_{\mathrm{rel}} \mathrm{SA}_{\mathrm{k}}$ can now be established as $[78,80]$ :

Performance $=\sum_{k=1}^{P} \frac{\text { PSA }_{\mathrm{k}}}{\text { SPSA }_{\mathrm{k}}} \times\left\{\frac{\mathrm{C}_{\mathrm{rel}} \mathrm{SA}_{\mathrm{k}}}{\sum_{k=1}^{P} \mathrm{C}_{\mathrm{rel}} \mathrm{SA}_{\mathrm{k}}}\right\}$

Where the performance in each maintenance system activity, $\mathrm{PSA}_{\mathrm{k}}$, is compared with a standard, SPSA $A_{k}$ and then weighted according to $\mathrm{C}_{\mathrm{rel}} \mathrm{SA}_{\mathrm{k}}$, that can be developed from the relationship:

$\mathrm{C}_{\mathrm{rel}} \mathrm{SA}_{\mathrm{k}}=\sum_{\mathrm{i}=1}^{\mathrm{N}} \mathrm{C}_{\mathrm{rel}} \mathrm{SA}_{\mathrm{k}} \mathrm{FA}_{\mathrm{i}} \times \mathrm{C}_{\mathrm{rel}} \mathrm{FA}_{\mathrm{i}}$

where $\mathrm{N}$ is the number of failure attributes identified. $\mathrm{C}_{\mathrm{rel}} \mathrm{FA}_{\mathrm{i}}$ represents the relative contribution of system activity $\mathrm{k}$ to failure attribute $\mathrm{i}$. This variable identifies that system activities are only relevant if they can influence the technical system's behaviour related to one or more significant failure attributes. The failure attribute behaviour is represented as: 
$\mathrm{C}_{\text {rel }} \mathrm{FA}_{\mathrm{k}}=\sum_{\mathrm{i}=1}^{\mathrm{N}} \mathrm{C}_{\text {rel }} \mathrm{FA}_{\mathrm{i}} \mathrm{OG}_{\mathrm{j}} \times \mathrm{C}_{\text {rel }} \mathrm{OG}_{\mathrm{j}}$

Here, $\mathrm{OG}_{\mathrm{j}}$ refers to the potential organization goals. The overall influence of the maintenance system on a particular failure attribute should be represented by a combination of the influence of the various system components and identified as $\mathrm{C}_{\mathrm{rel}} \mathrm{SA}_{\mathrm{k}}$. It is given by the expression:

$\mathrm{C}_{\mathrm{rel}} \mathrm{SA}_{\mathrm{k}}=\sum_{\mathrm{i}=1}^{\mathrm{N}} \mathrm{C}_{\mathrm{rel}} \mathrm{SA}_{\mathrm{k}} \mathrm{FA}_{\mathrm{i}} \times \mathrm{C}_{\mathrm{rel}} \mathrm{FA}_{\mathrm{i}}$

The total influence of the maintenance system on the organization's success, CIMS can then be determined, i.e.:

CIMS $=\sum_{\mathrm{i}=1}^{\mathrm{N}} \mathrm{C}_{\mathrm{rel}} \mathrm{SA}_{\mathrm{k}} \mathrm{FA}_{\mathrm{i}} \times \mathrm{C}_{\mathrm{rel}} \mathrm{FA}_{\mathrm{i}}$

CIMS $=\sum_{\mathrm{i}=1}^{\mathrm{P}} \mathrm{C}_{\mathrm{rel}} \mathrm{SA}_{\mathrm{i}}$

which forms the overall standard of performance. It is based on the best known maintenance systems available to reconcile equipment behaviour and operating practice with the organization's goals. Values of $\mathrm{C}_{\mathrm{rel}} \mathrm{SA}_{\mathrm{k}} \mathrm{FA}_{\mathrm{i}}$ must be obtained and are the prime determinants of the standard of performance derived here. The auditapproach appears to be viable, viz [78,80]:

- Performance stems from the system activities in place and their relevance to the situation.

- The standard results from the establishment of the 'best known' system activity relative to the technical systems concerned.

- The significance of performance of a given system activity is governed by its influence over or on the technical system's behaviour. Technical system behaviour is determined by its design, operation and maintenance in accordance with the behaviour desirable for the success of the organization.

Combining this result with the values obtained from equation (30), the performance contribution $\mathrm{PCSA}_{\mathrm{k}}$, of a system element can be determined by:

$\operatorname{PCSA}_{k}=\frac{\frac{\text { PSA }_{k}}{\text { SPSA }_{k}} \times C_{\text {rel }} \mathrm{SA}_{k}}{\sum \mathrm{C}_{\mathrm{rel}} \mathrm{SA}_{\mathrm{k}}}$

Note that the denominator is equivalent to the coefficient of influence of the maintenance. The summary of the audit systems approach is as follows $[12,78,80]$ : 
(i) Establish and rate the relevant organization goals as they may relate to the technical systems it employs and their relative importance or contribution, $\mathrm{C}_{\mathrm{rel}} \mathrm{OG}_{\mathrm{j}}$.

(ii) Determine $\mathrm{C}_{\mathrm{rel}} \mathrm{FA}_{\mathrm{i}} \mathrm{OG}_{\mathrm{j}}$ and hence $\mathrm{C}_{\mathrm{rel}} \mathrm{FA}_{\mathrm{i}}, \mathrm{i}=1,2, \ldots, \mathrm{N}$ : the importance of each failure attribute $\mathrm{FA}_{\mathrm{i}}$ to organizational success.

(iii) Identify the important system activities, $\mathrm{SA}_{\mathrm{k}}, \mathrm{k}=1,2, \ldots, \mathrm{p}$.

(iv) Establish $\mathrm{C}_{\mathrm{rel}} \mathrm{SA}_{\mathrm{k}} \mathrm{FA}_{\mathrm{i}}$ the contribution of system activities to each of the failure attributes, by expert opinion, for all $i$ and for $k=1,2, \ldots P$.

(v) Calculate the coefficient of influence of each identified system activity, and hence CIMS.

(vi) Determine the possible states of the system activities: the available options.

(vii) Select the 'best known' alternative from the available states for each system activity.

(viii) Determine, for each system activity, $\mathrm{PSA}_{\mathrm{k}}$, through comparison between the actual activity configuration and that identified in step vii.

(ix) Calculate PCSA .

(x) Calculate overall performance.

\subsection{Treatment method 4: Statistical/reliability/maintainability functional approach}

This approach has been used by a number of investigators [53,55-59,68]. The use of subsurvival functions for the analysis of censored reliability life data is an approach adopted for the evaluation of maintenance performance by some researchers [88]. Particularly, subsurvival functions are applied to operational data for the control rod drive systems of a Nordic nuclear reactor. When censoring is caused by preventive maintenance, these methods can be used to measure maintenance performance. The interest is to separate the effects of maintenance from the intrinsic reliability of the components as expressed in the naked failure rate, the failure rate which would be observed if no maintenance were performed. These notions are applied for the analysis of the control rod drive system for 8 Nordic nuclear power blocks. Data for this analysis come from a common failure reporting system (TUD).

Incidents were classified as 'corrective' and 'preventive' maintenance. The reporting system supports a provisional classification into corrective and preventive maintenance on the basis of the generic indicator for 'method of detection'. Detections by 'alarm', 'control' room monitoring', 'during visits of inspectors' and 'fortuitous discovery' were associated with corrective maintenance, other detection modes, such as 'test', 'preventive maintenance' and 'revision', were identified with preventive maintenance. The method employed to analyze this data is as follows: Good maintenance involves at least two and possibly three desiderata:

(i) Seeing very few corrective events;

(ii) Performing as little preventive maintenance as possible, and possibly

(iii) Inducing low naked failure rates for critical failure.

The 'naked failure rates for critical failure' is the rate at which critical failures would occur if no maintenance were performed. Seeing few corrective events is not 
valuable if it is achieved by maintaining the component so often that the primary mission is compromised, and performing little preventive maintenance is not valuable if the component often fails critically. A service sojourn is a time interval beginning when a component enters service, either for the first time or after repair, and ending when the component exits service for preventive or corrective maintenance. When the component is in service at the termination of the observation period, this service time is random right censored. The indicators for these three desiderata are:

\section{I: Indicator:}

For every time t: Probability of service sojourn $>t$ ending in corrective maintenance is less than Probability of service sojourn $>t$ ending in preventive maintenance.

I: Summary indicator: (set $\mathrm{t}=0$ above)

Probability corrective maintenance $<$ Probability preventive maintenance

\section{II: Indicator:}

For every time t: Probability of service sojourn > t GIVEN that it ends in corrective maintenance is almost equal to Probability of service sojourn $>$ t GIVEN that it ends in preventive maintenance

II: Summary Indicator:

Length of average corrective maintenance sojourn - Length of average preventive maintenance sojourn.

\section{III: Indicator}

If there were no censored observations, the naked critical failure rate (random signs model) is estimated as:

\section{\# Corrective events \\ $\overline{\text { Sum of corrective sojourn times }}$}

Terminating a service sojourn causes censoring by cutting off the observation period. This type of censoring is assumed independent of the maintenance policy. For exponential variables subject to independent censoring we would estimate.

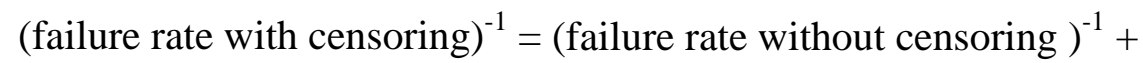
(total censored time) / (\#observations - \#censored observations)

Uncertainty in the naked failure rate estimate derives from two sources, namely sampling fluctuations and modeling uncertainty arising from lack of knowledge of the interaction of the corrective and preventive maintenance processes. An upper 
bound can be given which captures both types of uncertainty. Whatever the relation between corrective and preventive maintenance, we have:

Expected length of sojourn ending in corrective maintenance $>$

Expected length of sojourn ending for any reason whatever

Conclusions for the summary indicators of the three desiderata are given below:

I: $\quad$ For PL1, PL2 and Pl5 the probability of preventive maintenance is at least as great as that for corrective maintenance. This suggests that the preventive maintenance is indeed appropriate to the number of failures.

II: $\quad$ PL3, PL7 and PL8 would appear to be losing some effective service time due to preventive maintenance. Negative values for lost service time suggest that maintenance tends to be performed on components which have been in service longer than average.

III: PL1, PL2 and PL3 show the lowest naked critical failure rates. The naked failure rate estimate is still rather low.

\subsection{Treatment method 5: The composite formulation method}

The second research stream takes a normative decision theory perspective [63, 65]. The concept of nominal group technique (NGT) perhaps stimulated a compendium of interesting research, principally in the manufacturing industry. Presently, there is a databank of productivity studies using this approach at the Department of Industrial Engineering, University of Ibadan. For an extensive treatment of the composite formulation method consult Oluleye [65, 66].

As indicated in $[65,66]$, the composite formulation method has the following detailed steps on the procedure for measuring performance and instituting a corrective action needed for improvement [66]. Firstly, performance measures are obtained and ranked in order of decreasing importance. In the case of performance measures, the best is ranked $1^{\text {st }}$, while the next is ranked $2^{\text {nd }}$. The third best is ranked $3^{\text {rd }}$. Where initial $=1$. This is done until the last important measure is ranked $\varnothing^{\text {th }}$. The best and worst performance for each measure is considered over a chosen span of time. Taking note of the aim of each measure identifies this. Such aims may include minimization or maximization of indices. For example, maximization of efficiency, utilisation, and minimization of cost of downtime are sought. Appropriate utility values of 1.0 and 0 are then assigned respectively.

The nominal group technique members then allot utility values to intermediate values within the range 1.0 and 0 . Utility curves are developed using the allotted values for each measure. Also, the nominal group technique members allot weighting factor to ranked measures such that $[63,66]$ :

If $\mathrm{R}_{\mathrm{i}}<\mathrm{R}_{\mathrm{i}+1}$, then $\mathrm{W}_{\mathrm{i}}>\mathrm{W}_{\mathrm{i}+1}$ 
where $\mathrm{R}_{\mathrm{i}}=$ rank of performance measure $\mathrm{i}, \mathrm{W}_{\mathrm{i}}=$ weight allotted to performance measure $\mathrm{i}$. The weighting factor indicates the degree of importance of a measure in relation to the set objective. Also, scaling factors for the measures are obtained by using the relationship:

$\mathrm{K}_{\mathrm{i}}=\mathrm{W}_{\mathrm{i}} /\left(\mathrm{W}_{1}+\mathrm{W}_{2}+\ldots, \mathrm{W}_{\mathrm{n}}\right)$

Where $\mathrm{i}=1,2, \ldots, \mathrm{n}$;

$\mathrm{K}_{\mathrm{i}}=$ scaling factor for measure $\mathrm{i}$,

$\mathrm{n}=$ number of performance measures used in composing index.

Oluleye [66] proposed a scaling factor to normalise the composite index. In addition Oluleye [66] used utility curves to determine the overall effectiveness index. In calculating the contribution of a measure, a formula that relates utility value to scaling factor was further proposed by Oluleye [66] as::

$\mathrm{C}_{\mathrm{i}}=\mathrm{U}_{\mathrm{i}} \times \mathrm{K}_{\mathrm{i}}$

It follows that $\mathrm{C}_{\mathrm{i}}=$ contribution of performance measure $\mathrm{i}$, to the target index, $\mathrm{U}_{\mathrm{i}}=$ utility value of target for performance measure $\mathrm{i}$, $\mathrm{K}_{\mathrm{i}}$ is the scaling factor for performance measure $\mathrm{i}$.

In sum, the composite target index, defined as T, is expressed as:

$\mathrm{T}=\left(\mathrm{C}_{1}+\mathrm{C}_{2}+----+\mathrm{C}_{\mathrm{n}}\right)$.

\subsection{Treatment method 6: Partial maintenance productivity approach}

The approach here is Input-Output based. Partial factor productivity is defined as the ratio of total output to single input [51]:

Partial Factor Productivity $=\frac{\text { Total output }}{\text { Single input }}$

Lofsten [51] expressed the total output as the availability and amount of production. The model is based on the idea that good productivity is achieved when the total maintenance costs and downtime costs are reduced to a minimum level for the state of production system, i.e. the minimum production rate is fulfilled. The method involves first carrying out an object analysis of each individual maintenance object, i.e. a bottleneck machine $(i, j, \ldots, n)$, in the case of an operation on machine $n$. The next stage consists of carrying out a resource allocation analysis. Here, one chooses a combination of measures from each object that uses the available limited resources. The inputs are represented by

$$
\text { Inputs }_{n}=\operatorname{Min} \sum_{t=1}^{T} \frac{C_{t}\left(\mathrm{PM}_{t}, \mathrm{CM}_{t}, \mathrm{~S}_{\mathrm{t}}\right)}{(1+\mathrm{i})^{\mathrm{t}}}
$$


Here, $C_{t}$ is the total cost in period $t$. It is the sum of the expected maintenance cost and down time cost. $\mathrm{T}$ is the reinvestment occurring in time T. Expected machine life (in years), $t$ the period $t$ (in years), $i$ the interest rate, PM the preventive maintenance in period $\mathrm{t}$ (in dollars). The variable $\mathrm{PM}_{\mathrm{t}}$ denotes the period in which preventive maintenance job starts, and the corrective maintenance in period t (in dollars), and $\mathrm{s}$ the state of the machine, and $S_{t}=f(i, j, \ldots, n)$. The state of the machine can, by preventive maintenance, be improved (i.e. $0,1,2,3, \ldots . ., S_{\max }$ ). The output is expressed as:

Output $=\sum_{t=1}^{J} \frac{R_{t}\left(V_{n}, P_{a}, A_{n}\right)}{(1+i)^{t}}$

where $\mathrm{R}$ is the revenue in period $\mathrm{t}, \mathrm{V}$ the production volume, and $\mathrm{P}$ the price of products in different stages in the production system where $t=(i, j, \ldots, n)$ and $A_{n}$ is the availability.

Throughout the productivity literature there appears to have been arguments adduced: why productivity should be measured in terms of input and output. Unfortunately, no documentation exists on attempts to measure maintenance productivity from the above perspective. Lofsten's work perhaps represents the first documented evidence to adopt the conceptual input-output view of maintenance productivity. However, it seems desirable to set for the certain dimensions of the model that could be helpful for practitioners. Clearly, the issue of target setting and monitoring with respect to the utilisation of input resources for certain output levels needs to be pursued by future investigators. It is hoped that some readers may also be interested to advance a study of the method by which mathematical logic can be made helpful in investigating the traditional problems of input-output analysis. That is a topic with which Lofsten's paper has not attempted to deal with.

\section{CONCLUSIONS}

This paper takes a first step to encourage investigations and debates on the maintenance performance issue. The argument presented here suggests a reasonable explanation of the present level of understanding of maintenance performance research. It is suggested, that, although many critical issues have been raised, and some answers offered, a number of arguments are ready for empirical investigation and scrutiny.

It is hoped that future investigators will not only challenge and test the primary arguments and ideas presented here, but will also refine and extend them. Such efforts are critical to understanding the effect of the relationship between important interacting variables and to develop a balanced view of these relationships.

The paper has articulated the multiple criticisms usually offered against composite model formulation when using surrogate indices for the maintenance function. The research was motivated by the following observations. Firstly, even though the problem of composing an integrated index using surrogate measures has been the focus of some studies, very little documentation exists to show that the problems that usually arise due to composite model formulation have been solved. Such include 
duplicity of measures, etc (see $[63,66])$. In many cases where the issue is raised it has only been mentioned for further study.

One potentially fruitful avenue for future investigation is the possible elimination of duplicity in composite formulation by restructuring the measures used with the use of neuro-fuzzy and analytical hierarchy process (AHP) concepts. Perhaps this would be the most immediate useful follow-on study. Another attractive area for inquiry is how subjectivity could be reduced in composite formulation.

\section{REFERENCES}

[1] Armitage P., Jardine, A.K.S., 1968. "A decision problem", International Journal of Production Research, Vol. 7, No. 1, pp. 7 - 15.

[2] Al-Najjar B., Alsyouf I., 2004. "Enhancing a company's profitability and competitiveness using integrated vibration-based maintenance: A case study" European Journal of Operational Research, Vol. 157, pp. 643-657.

[3] Arts R.H., Knapp G.M., Mann L. Jr., 1998. "Some aspects of measuring maintenance performance in the process industry" Journal of Quality in Maintenance Engineering Vol. 4, No. 1, pp. 6-11.

[4] Bamber, C.J., Castka, P., Sharp, J.M. and Motara, Y. 2003. "Crossfunctional team working for overall equipment effectiveness (OEE)”, Journal of Quality in Maintenance Engineering, Vol. 9, No. 3, p. 223-238.

[5] Blanchard, S.B., 1997. "An enhanced approach for implementing total productive maintenance in the manufacturing environment”, Journal of Quality in Maintenance Engineering, Vol. 3, No. 2, pp. 69-80.

[6] Coetzee, J.L., 1999. "A holistic approach to the maintenance "problem", Journal of Quality in Maintenance Engineering, Vol. 5, No. 3, pp. 276-281.

[7] Coetzee, J.L., 1997. "Maintenance", Maintenance Publishers, Pretoria, Chapter 11.

[8] Chan K.T., Lee R.T.H., Burnett J., 2001. "Maintenance performance: a case study of hospitality engineering systems", Facilities, Vol. 19, No. 13, pp. 494 504.

[9] Cooke, R. Paulsen, J., 1997. "Concepts for measuring maintenance performance and methods for analysing competing failure modes", Reliability Engineering and System Safety, Vol. 55, pp. 135-141.

[10] De Groote P., 1995. "Maintenance performance analysis: A practical approach", Journal of Quality in Maintenance Engineering, Vol. 1, No. 2, pp. 4-24.

[11] Duffua, S.O., Raouff, A., 1997. "Continuous maintenance productivity improvement using structured audit", International Journal of Industrial Engineering, Vol. 3, No. 3, pp. 151-160.

[12] Dwight, R. 1999. "Frameworks for measuring the performance of the maintenance system in a capital intensive organization", $\mathrm{PhD}$ Thesis, Department of Mechanical Engineering, University of Wollongong, Wollongong.

[13] Dwight R., 1999. "Searching for real maintenance performance measures", Journal of Quality in Maintenance Engineering, Vol. 5, No. 3, pp. 258-275. 
[14] Ellingsen H. P., Kumar U., Liyanage J.P., Tønnesen N., Hamre R., Nilsen N. M., Waldeland R., Nerhus O., Espeland Ø., 2001. "Development of a methodology for the usage and implementation of operation \& maintenance performance indicators (task 7-d)", Project on the Development and Implementation of Operations \& Maintenance $(O \& M)$ Performance Indicators, PI-TEC-T7\&9/REV0.

[15] Ellingsen H. P., Tønnesen N., Hamre R., Nilsen N. M., Waldeland R., Nerhus O., Kumar U., Espeland Ø., Liyanage J.P., 2001. "Development of a performance framework (task 6-b)", Project on the Development and Implementation of Operations \& Maintenance (O\&M) Performance Indicators, PI-TEC-T6/REV0.

[16] Geraerds W.M.J., 1990. "The EUT-maintenance model", IFRIM-report 90/01, Eindhoven.

[17] Hamlin, J.L, 1979. "Productivity appraisal for a maintenance centre", Industrial Engineering, Vol. 11, No. 9

[18] Hemu, M., 2000. "Using benchmark data effectively sustainable maintenance performance targets in our industry", Journal of Maintenance and Asset Management, Vol. 15, No. 3. (July/August).

[19] Jooste J.L. and Page D.C., 2004, "A performance management model for physical asset management", South African Journal of Industrial Engineering, Vol. 15, Issue 2, pp. 45-66.

[20] Kay, E., 1976. "The effectiveness of preventive maintenance", International Journal of Production Research, Vol. 14, No. 3, pp. 329-344.

[21] Komonen, K., 1998. "The structure and effectiveness of industrial maintenance”, Ph.D. Dissertation, Helsinki University of Technology, Department of Industrial Economics, Espoo, (in Finnish).

[22] Kincaid D.G., 1994. "Measuring performance in facility management", Facilities, Vol. 12, No. 6, pp. 17-20.

[23] Kumar, U. and Ellingsen, H.P. 2000. "Development and implementation of maintenance performance indicators for the Norwegian oil and gas industry", Proceedings of the Euromaintenance-2000 Conference, pp. 221-226.

[24] Kumar U., Liyanage, J., 2000. "A strategically balanced measurement system for maintenance process: Some foundational issues for a development method (Part II) ", Maintenance \& Operations, Vol. 4, No. 3, pp. 147-155.

[25] Kumar U., Liyanage, J., 2000. "Value based maintenance: An agenda to streamline operations and maintenance performance to improve process profitability", The 2nd European Petrochemical Technology Conference (EPTC-2000), Prague, Czech Republic.

[26] Kumar U., Liyanage, J., 2000. "Design \& development of maintenance measurement system for the offshore industry", Proceedings of the 3rd International Quality-Reliability-Maintainability Conference (QRM-2000), Oxford, UK.

[27] Kumar U., Liyanage, J., 2000. "In search of maintenance performance excellence: Utility of performance indicators in knowledge management \& process intelligence", Asset \& Maintenance Day -2000 in Rogaland Seminar, Stavanger, Norway.

[28] Kumar, U., Liyanage, J.P., 2000. "On the development and use of performance measures for maintenance management in the mining industry", 
The International Conference on Technology Management in Mining Processing and Environment, pp 303-312.

[29] Kumar U., Liyanage, J., 2001. "The process of maintenance performance management in an integrated plant environment: Setting the foundation for a new perspective (in Spanish)", Engineering, Production \& Maintenance (Gestion de Activos Industriales), Vol. 4, No. 15, pp. 37-47.

[30] Kumar U., Liyanage, J., 2002. "Adjusting maintenance policy to business conditions: Value-based maintenance performance measurement", in Proceedings of the International Foundation for Research in Maintenance, Maintenance Management and Modeling Conference, , Vaxjo, Sweden, Paper No. 20.

[31] Kutucuoglu K.Y., Hamali J., Irani Z., Sharp J.M., 2001. "A framework for managing maintenance using performance measurement systems" International Journal of Operations \& Production Management, Vol. 21, No. 1/2, pp. 173-194.

[32] Laakso, K., "Assessing the effectiveness of a maintenance programme", Journal of Maintenance and Asset Management, Vol. 12, No. 1.

[33] Labib, A.W., O'Conor R.F., Williams G.B., 1998. "An effective maintenance system using the analytical hierarchy process", Integrated Manufacturing Systems, Vol. 9, No. 2, pp. 87-98.

[34] Liyanage, J.P., 1999. "The process of maintenance performance management (Task 4 supplementary report)", Project on the Development and Implementation of Operations \& Maintenance Performance Indicators, PITEC-T4/REV2-SUPP.

[35] Liyanage, J.P., 2003. "Operations and maintenance performance in oil and gas production assets: Theoretical architecture and capital value theory in perspective", $P h D$ Thesis, Department of Mechanical Engineering, Norwegian University of Science \& Technology, Norway.

[36] Liyanage, J.P., et al. 2003. "Development of indicators (Task 5)", Project on the Development and Implementation of Operations \& Maintenance (O\&M) Performance Indicators, PI-TEC-T5/REV0.

[37] Liyanage, J.P., Kumar, U., 2000. "A strategically balanced measurement system for maintenance process: Some foundational issues for a development method (Part I)", Maintenance \& Operations, Vol. 4, No. 2, pp 79-87.

[38] Liyanage, J.P., Kumar, U., 2000. "Measuring maintenance process performance using the balanced scorecard", The 15th European Maintenance Congress: Euromaintenance 2000, pp 25-32.

[39] Liyanage, J.P., Kumar, U., 2000. "The process of maintenance performance management in an integrated plant environment: Setting the foundation for a new perspective", Engineering, Production \& Maintenance „, Vol.4, No.15., pp 37-47.

[40] Liyanage, J.P. and Kumar, U. 2000a. "Utility of maintenance performance indicators in consolidating technical and operational health beyond the regulatory compliance”, in Doerr, W.W. (Ed), Safety Engineering and Risk Analysis: The International Mechanical Engineering Congress and Exposition2000, pp. 153-60. 
[41] Liyanage, J.P., Kumar, 2001. "VBM \& BSC: An adaptive performance measurement system using the balanced scorecard", Journal of Maintenance \& Asset Management, Vol.16., No.2, pp 12-21.

[42] Liyanage, J.P., Kumar, U., 2001. "In search of performance excellence in asset maintenance: Performance indicators, knowledge management \& process intelligence", The Maintenance Journal, Vol.14, No.1, pp 54-64.

[43] Liyanage, J.P., Kumar, U., 2001. "Value based maintenance performance diagnostics: An architecture to measure maintenance performance in petroleum assets", The International Conference of Maintenance Societies (ICOMS2001), Paper no. 050.

[44] Liyanage, J.P., Kumar, U., 2002. "A value-based working algorithm to manage maintenance performance: Key learning points from oil \& gas industry about an integrated production asset", New Engineer Journal, Vol. 4, No.4, pp 5-7.

[45] Liyanage, J.P., Markeset, T., Kumar, U., 2001. "On the knowledge driven maintenance performance management grounded in process intelligence: With applications to asset maintenance and product development", The 2nd European Conference on Intelligent Management Systems in Operations (IMSIO-2001), pp 39-486.

[46] Liyanage, J.P., Osmundsen, P., Kumar, U., 2003. "A global framework to manage maintenance performance to condition plant health: Reflections from the Norwegian oil \& gas industry, To appear in the International Journal of Condition monitoring and Diagnostic engineering management.

[47] Liyanage, J.P., Selmer, C.V., 1999. "Establishment of an engineering methodology and a structure for a measurement system within the operations and maintenance process (Task 2\&3)", Project on the Development and Implementation of Operations \& Maintenance $(O \& M)$ Performance Indicators, PI-TEC-T2\&3/REV0.

[48] Liyanage, J., Kumar U., 2002. "Process of maintenance performance management and its imperatives within the offshore petroleum industry (PartI): The emerging environment for asset maintenance in the new business economy", SMRP Solutions (Online), Vol. 4.

[49] Ljungberg, O., 1998. "Measurement of overall equipment effectiveness as a basis for TPM activities", International Journal of Operations and Production, Vol. 18, No. 5, pp. 495-507.

[50] Lofsten, H., 1999. "Management of industrial maintenance - economic evaluation of maintenance policies", International Journal of Operations and Production, Vol. 19, No. 7, pp. 716-737.

[51] Lofsten, H., 2000. "Measuring maintenance performance: In search for a maintenance productivity Index", International Journal of Production Economics, Vol. 63, pp. 47-58.

[52] Luck W.S., 1965. "Now you can really measure maintenance performance, Factory Management and Maintenance", McGraw-Hill, Vol. 114, pp. 81-86.

[53] Markeset, T., Liyanage, J., Korte, J., Kumar U., 2001. "Value \& risk: A balanced performance assessment criterion for maintenance in offshore engineering constructions", in Proceedings of the $11^{\text {th }}$ International Offshore \& Polar Engineering Conference (ISOPE-2001), Stavanger, Norway. 
[54] Markeset, T., Kumar U., Liyanage, J., 2001. "On the knowledge driven maintenance performance management grounded in process intelligence: With applications to asset maintenance and product development", in Proceedings of the The 2nd European Conference on Intelligent Management Systems in Operations (IMSIO-2001), Salford, UK.

[55] Martorell, S., Sanchez, A., Muñoz, A., Pitarch, J.L., Serradell, V., Roldan, J., 1999. "The use of maintenance indicators to evaluate the effects of maintenance programs on NPP performance and safety", Reliability Engineering and System Safety, Vol. 65, Issue 2, pp. 85-94.

[56] Martorell, A., Sanchez, A., Nunoz, A., Pitarch, J.L., Carlos, S., Serradel, V., Nunez, A., 1998. "Methodology and applications of a maintenance evaluation programme", TOP SAFE '98, Actas, Valencia, Espance.

[57] Martorell, A., Sanchez, A., Nunoz, A., Pitarch, J.L., Carlos, S., Serradel, V., Roldan, J., Balkem, A.A., 1998. "Application of a maintenance evaluation program to improve NPP performance and safety", ESREL '98.

[58] Martorell, A., Serradel, V., Sanchez, A., Nunoz, A., Roldan, J., Sola, A., 1996. "Follow-up maintenance effectiveness within a reliability centred maintenance living program", Probabilistic Safety Assessment and Management '96, ESREL '96 - PSAM - III, Springer - Verlag.

[59] Mitchell, A., 1981. "Optimising maintenance benefits", Hydrocarbon Processing, pp. 9-12.

[60] Nakajima, S., 1988. “An introduction to TPM”, Production Press, Cambridge, MA.

[61] Nakajima, S., 1989. “ТPM development programme”, Production Press, Cambridge, MA.

[62] Mobley, R.K., 1998. Total plant performance management, TWI Press, Inc.

[63] Oke, S.A., Oluleye, A.E., 1999. "A template for composing maintenance performance measures", Conference Proceedings of the Nigerian Institute of Industrial Engineers, pp. 114-125.

[64] Oke S.A., 2005. "An analytical model for the optimisation of maintenance profitability", International Journal of Productivity and Performance Management, Vol. 54, No. 2, pp. 113-136.

[65] Oluleye, A.E., Gbadebori, S.O., 2000. "Maintenance system evaluation: Case of a food company", Conference on Performance Measurement 2000 - Past, Present and Future, Cambridge, England.

[66] Oluleye, A.E., Tade, A.O., Olajire, K.A., 1997. "A schema for assessing maintenance effectiveness", $7^{\text {th }}$ International Management of Industrial Reliability and Cost Effectiveness Symposium, University of Exeter, United Kingdom, pp. 331 - 341.

[67] Osmundsen, P., Liyanage, J., Kumar U., 2001. "A pathfinder for value based maintenance in the 21st century: A structured technique for an operations \& maintenance scorecard for process industries", in The 3rd Middle East Refining \& Petrochemicals Exhibition \& Conference (PETROTECH-2001), Bahrain.

[68] Paulsen, J., Cooke, R., Nyman, R., 1997. "Comparative evaluation of maintenance performance using subsurvival functions", Reliability Engineering and System Safety Vol. 58, No. 2, pp. 157-163. 
[69] Pintelon, L., Van Puyvelde F., 1997. "Maintenance performance reporting systems: some experiences", Journal of Quality in Maintenance Engineering, Vol. 3, No. 1, pp. 4-15.

[70] Potter, D.G., 1986. "Using indices to monitor maintenance performance", Journal of Maintenance and Asset Management, Vol. 1, No. 3.

[71] Priel, V.Z., 1962. "Twenty ways to track maintenance performance”, Factory.

[72] Priel, V.Z., 1974. Systematic Maintenance Organisation, MacDonald \& Evans Ltd., London.

[73] Pun K., Chin K., Chow M., Lau H.C.W., 2002. "An effectiveness-centred approach to maintenance management: A case study", Journal of Quality in Maintenance Engineering, Vol. 8 No. 4, pp. 346-368.

[74] Raouf A., 1993. "On evaluating maintenance performance", International Journal of Quality \& Reliability Management, Vol. 10, No. 3.

[75] Shohet I.M., 2003. "Key performance indicators for maintenance of healthcare facilities", Facilities, Vol. 21, No. 1, pp. 5-12.

[76] Steelandt, Gelders, 1981. "The profit effectiveness of maintenance decisions: A case study", International Journal of Production Research, Vol. 19, No. 4, pp. 441 - 456.

[77] Swanson L., 2001. "Linking maintenance strategies to performance", International Journal of Production Economics, Vol. 70, Issue 3, pp. 237 244.

[78] Tsang, A.H.C. 1999. "Maintenance performance management in capital intensive organizations", $\mathrm{PhD}$ Thesis, Department of Manufacturing Engineering, The Hong Kong Polytechnic University, Hong Kong.

[79] Tsang, A.H.C. and Brown, W.L. 1998. "Managing the maintenance performance of an electric utility through use of balanced scorecard", Proceedings of the $3^{\text {rd }}$ International Conference on Maintenance Societies, paper 022.

[80] Tsang A.H.C., 1998. "A strategic approach to managing maintenance performance", Journal of Quality in Maintenance Engineering, Vol. 4, No. 2, pp. 87-94.

[81] Vatland, H.A., Ellingsen, H.P., Liyanage, J.P., Viland, L., 1999. "Summary report on study and analysis of the existing performance indicators (Task1)", Project on the Development and Implementation of Operations \& Maintenance (O\&M) Performance Indicators, PI-TEC-T1/REV0.

[82] Vineyard, M., Amoako-Gyampah, K., Meredith, J.R., 2000. "An evaluation of maintenance policies for flexible manufacturing systems", International Journal of Operations and Production Management, Vol. 20, No. 4, pp. 409426.

[83] Visser, J.K., Pretorius, M.W., 2003. "The development of a performance measurement system for maintenance", South African Journal of Industrial Engineering, Vol. 14, Issue 1, pp. 83-98.

[84] Wireman, T., 1999. "Developing performance indicators for managing maintenance" TWI Press, USA. 


\section{ACKNOWLEDGEMENT}

The author gratefully acknowledges the immense contributions of the anonymous reviewers of this paper. He also thanks Professor J.K. Visser, University of Pretoria, South Africa and Joel Levitt of Maintenance Trainers, Inc., USA for their comments on earlier drafts of this article. In addition, thanks to Professor A. E. Oluleye, under whose guidance related research was conducted while the author was a student at the University of Ibadan, Nigeria. 